\title{
Economic burden of ventilator associated pneumonia in a developing country
}

\author{
E Alp ${ }^{1 *}, G$ Kalin $^{2}$, R Coskun², M Sungur ${ }^{2}, M$ Guven ${ }^{2}$, M Doganay $^{2}$ \\ From International Conference on Prevention \& Infection Control (ICPIC 2011) \\ Geneva, Switzerland. 29 June - 2 July 2011
}

\section{Introduction / objectives}

There is limited data about the economic burden of ventilator associated pneumonia (VAP) in developing countriesTo investigate incidence, risk factors, etiological agents, antimicrobial susceptibility rates and economic burden of VAP in a medical intensive care unit (MICU) of a developing country.

\section{Methods}

All patients on mechanical ventilation were followed up during one year in MICU.

\section{Results}

During the one-year period, 159 patients were followed up.Mean age was $61.82 \pm 16.81$. VAP developed in 96 (60\%) patients with 37.2/1000 ventilation days.The mean APCAHE II score was $24.32 \pm 5.94$, and there was no difference between VAP and non-VAP patients.Median mechanical ventilation days for non-VAP patients were 3 days (1-15 days).Mortality rate for non-VAP patients was $88.5 \%$, and the median time for death was 4 th day of hospitalization.Median time for VAP development was 5.5 days (2-25 days).Acinetobacter baumannii (42\%) and Pseudomonas aeruginosa (20\%) were the most common pathogens.All microorganisms were multi-resistant. Imipenem resistance of A.baumannii and P.aeruginosa was $92 \%$ and $71 \%$, respectively. The most significant risk factors for VAP were stay in hospital before MICU (OR:3.11) and length of stay in MICU (1.47). Mortality rate for VAP-patients was $80 \%$ and there was no statistically difference between the mortality rates of VAP and non-VAP patients. Median total cost of non-VAP patients in ICU was 2315 Euro, whereas it was 6308 Euro in VAP patients. Also, cost of ICU (253\&908

${ }^{1}$ Infectious Diseases and Clinical Microbiology, Erciyes University, Kayseri, Turkey

Full list of author information is available at the end of the article
Euro), antibiotics (230\&810 Euro), laboratory (370\&979 Euro) and clinical (371\&878 Euro) were higher in VAP patients.

\section{Conclusion}

The cost of VAP is approximately three-fold higher than non-VAP patients. Infection control standards should be assessed and rigorously reinforced in "limited-resources" countries.

\section{Disclosure of interest}

None declared.

\section{Author details}

${ }^{1}$ Infectious Diseases and Clinical Microbiology, Erciyes University, Kayseri, Turkey. ${ }^{2}$ Erciyes University, Kayseri, Turkey.

Published: 29 June 2011

doi:10.1186/1753-6561-5-S6-P65

Cite this article as: Alp et al:: Economic burden of ventilator associated pneumonia in a developing country. BMC Proceedings 2011 5(Suppl 6): P65.

Submit your next manuscript to BioMed Central and take full advantage of:

- Convenient online submission

- Thorough peer review

- No space constraints or color figure charges

- Immediate publication on acceptance

- Inclusion in PubMed, CAS, Scopus and Google Scholar

- Research which is freely available for redistribution

\section{Biomed Central}

(c) 2011 Alp et al; licensee BioMed Central Ltd. This is an open access article distributed under the terms of the Creative Commons Attribution License (http://creativecommons.org/licenses/by/2.0), which permits unrestricted use, distribution, and reproduction in any medium, provided the original work is properly cited. 